\title{
Regulation of the GTP-binding protein-based antilipolytic system of sheep adipocytes by growth hormone
}

\author{
R A Doris ${ }^{1,2}$, E Kilgour ${ }^{1}$, M D Houslay ${ }^{2}$ and R G Vernon ${ }^{1}$ \\ ${ }^{1}$ Hannah Research Institute, Ayr, Scotland, UK and ${ }^{2}$ IBLS, University of Glasgow, Glasgow G12 8QQ, UK \\ (Requests for offprints should be addressed to R G Vernon, Hannah Research Institute, Ayr KA6 5HL, Scotland)
}

\begin{abstract}
Chronic exposure of sheep adipose tissue to growth hormone $(\mathrm{GH})$ in vitro decreases the ability of the adenosine analogue, $N^{6}$-phenylisopropyladenosine (PIA), to inhibit isoprenaline-stimulated lipolysis by a mechanism which is dependent on both gene transcription and protein serine/threonine phosphorylation. The inhibition is not due to a change in ligand binding to the adenosine receptor, the amounts of the three isoforms of the inhibitory GTP-binding protein, $\mathrm{G}_{\mathrm{i}}$, or the maximum (forskolin-stimulated) adenylate cyclase activity. The ability of $\mathrm{GH}$ to modulate the PIA-activated adenosine receptor to stimulate dissociation of heterotrimeric $G_{i}$ was assessed by measurement of pertussis toxin-catalysed
\end{abstract}

ADP-ribosylation of $\mathrm{G}_{\mathrm{i}}$; $\mathrm{GH}$ does not appear to alter the interaction between the activated receptor and $G_{i}$. The ability of $\mathrm{GH}$ to alter the ability of activated $\mathrm{G}_{\mathrm{i}}$ to inhibit adenylate cyclase activity was assessed by measuring the ability of a GTP analogue, guanosine $5^{\prime}-[\beta \gamma-$ imido]triphosphate ( $\mathrm{p}[\mathrm{NH}] \mathrm{ppG}$ ), to inhibit forskolinstimulated adenylate cyclase activity; chronic exposure to $\mathrm{GH}$ prevented this effect of $\mathrm{p}[\mathrm{NH}] \mathrm{ppG}$. Thus the attenuation of the inhibition of lipolysis by PIA by chronic exposure of adipocytes to $\mathrm{GH}$ appears to be due to an impairment in the interaction between adenylate cyclase and the $\alpha$ subunit of one or more isoforms of $G_{i}$. Journal of Endocrinology (1998) 158, 295-303

\section{Introduction}

Growth hormone (GH) acts chronically to increase lipolysis in adipocytes by several mechanisms including both an increased response and sensitivity to $\beta$-adrenergic agonists and a decreased response and sensitivity to antilipolytic factors such as adenosine and prostaglandin E, the relative importance of these mechanisms depending on the physiological state of the animal (Vernon et al. 1987, 1993, Goodman et al. 1988, Watt et al. 1991, Beauville et al. 1992, Yang et al. 1995, Doris et al. 1994, 1996, Dante et al. 1995, Houseknecht et al. 1995). The increased response and sensitivity to $\beta$-adrenergic agents induced by $\mathrm{GH}$ appears to be due to increases in the number of $\beta$-adrenergic receptors (Watt et al. 1991, Vernon et al. 1993, Yang et al. 1995, Doris et al. 1996) and also a change in the ability of hormone-sensitive lipase to translocate to the fat droplet on activation (Vernon et al. 1993).

Locally produced antilipolytic factors such as adenosine and prostaglandin $\mathrm{E}$ interact with their own receptors on the cell surface and this results in the dissociation and activation of isoforms of the heterotrimeric inhibitory GTP-binding protein, $\mathrm{G}_{\mathrm{i}}$, into their $\alpha$ and their $\beta$ plus $\gamma$ subunits (Birnbaumer et al. 1990, Houslay 1994). Three isoforms of $G_{i}$ have been identified, all having distinct $\alpha$ subunits $\left(G_{\mathrm{i}} 1 \alpha, \mathrm{G}_{\mathrm{i}} 2 \alpha\right.$ and $\left.\mathrm{G}_{\mathrm{i}} 3 \alpha\right)$ and common $\beta$ and $\gamma$ subunits (Birnbaumer et al. 1990, Houslay 1994). While all three isoforms are present in adipose tissue (Mitchell et al. 1989), $G_{i} 2$ appears to be the form primarily involved in transmitting the inhibitory signal from the adenosine (A1) receptor to adenylate cyclase (Houslay 1994, Kalkbrenner et al. 1996), although $\mathrm{G}_{\mathrm{i}} 1$ and/or $\mathrm{G}_{\mathrm{i}} 3$ can also transmit signal from the adenosine receptor to some extent, at least in the absence of $G_{i} 2$ (Rudolph et al. 1996).

Lowering serum GH concentrations in rats with a specific antiserum increased sensitivity (but not maximum response) to the adenosine analogue $N^{6}$ phenylisopropyladenosine (PIA), and this was associated with an increase in the amount of the $\alpha$ subunit of $G_{2} 2$; ligand binding to the adenosine receptor and the amounts of the $\alpha$ subunits of $\mathrm{G}_{\mathrm{i}} 1$ and $\mathrm{G}_{\mathrm{i}} 3$ were unchanged (Doris et al. 1994). Treatment of such rats with ovine GH reversed the effects of the antiserum on both sensitivity to PIA and amount of $\mathrm{G}_{\mathrm{i}} 2$ (Doris et al. 1994).

In contrast to the above, chronic treatment of sheep (Doris et al. 1996) or cows (Houseknecht \& Bauman 1997) in vivo with GH decreased maximum response of adipocytes to PIA but had no effect on either the number of adenosine receptors or the amount of $\mathrm{G}_{\mathrm{i}} 1$ plus $\mathrm{G}_{\mathrm{i}} 2$. In the present study we show that maintenance of explants of sheep adipose tissue in culture for $24 \mathrm{~h}$ with $\mathrm{GH}$ mimics the effect of treating sheep in vivo with the hormone on the response of lipolysis to PIA, and then we use this culture system to show that GH impairs the ability of one or more 
isoforms of $G_{i}$ to interact with adenylate cyclase by a mechanism that involves both protein serine/threonine phosphorylation and gene transcription.

\section{Materials and Methods}

\section{Animals}

Finn $\times$ Dorset-horn cross-bred, castrated male sheep aged 6-8 months were used and were fed a diet of cereals (300 g/day) plus hay available ad libitum for at least 4 weeks before sampling. On the day of killing, sheep were anaesthetised by injection of 20-30 $\mathrm{ml}$ Sagatal (Veterinary Drug Co., Falkirk, Scotland, UK) into the jugular vein. They were then exsanguinated and samples of subcutaneous adipose tissue were removed asceptically from the flank fat pads immediately anterior to the hind limbs. The samples were placed immediately in sterile $0.15 \mathrm{M}$ $\mathrm{NaCl}$ at $37^{\circ} \mathrm{C}$.

\section{Tissue culture}

Explants weighing about $15 \mathrm{mg}$ were cut using scissors and cultured in Medium 199 with Earle's salts, L-glutamine, $25 \mathrm{mM}$ Hepes (pH 7.3) (Gibco Biocult, Paisley, Strathclyde, Scotland, UK), $2.6 \mathrm{mM}$ acetate (final concentration) and antibiotics (Robertson et al. 1982). Tissue was preincubated in the culture medium for $22 \mathrm{~h}$ after which it was transferred to fresh culture medium plus or minus $4.5 \mathrm{nM} \mathrm{GH}$ and other agents as indicated in the text and tables and maintained in culture for a further period of $24 \mathrm{~h}$. Ovine pituitary $\mathrm{GH}$ was a gift from NIADDK, Bethesda, MD, USA; H7 was from Scientific Marketing, Barnet, Herts, UK; okadaic acid was from Calbiochem-Novabiochem (UK) Ltd, Nottingham, Notts, UK; phorbol myristyl acetate (PMA) was from Sigma-Aldrich, Poole, Dorset, UK. Okadaic acid and PMA were dissolved in dimethyl sulphoxide (DMSO) and subsequently diluted with Medium 199; maximum DMSO concentration in the culture medium was $1 \mu \mathrm{l} / \mathrm{ml}$; this concentration had no effect on the variables measured in the study.

\section{Lipolysis}

Pieces of adipose tissue before or after maintenance in culture were transferred to flasks containing $2.5 \mathrm{ml}$ Krebs-Ringer bicarbonate buffer (Krebs \& Hensleit 1933) (containing $1.22 \mathrm{mM} \mathrm{CaCl}{ }_{2}$ ) with $25 \mathrm{mM}$ Hepes buffer, pH $7 \cdot 4,5 \cdot 5 \mathrm{mM}$ glucose, $2 \mathrm{mM}$ acetate and $30 \mathrm{mg} / \mathrm{ml}$ BSA (fatty acid-free and dialysed) (Hanson \& Ballard 1968). Other agents were added as indicated in the text and tables. Adenosine deaminase, when added, was dialysed overnight before use. Tissue was incubated for $3 \mathrm{~h}$ at $37^{\circ} \mathrm{C}$ after which samples of medium were removed, deproteinised and stored at $-20{ }^{\circ} \mathrm{C}$ until assayed for glycerol (Plested et al. 1987). Adipocyte mean cell volume and number/g tissue were determined as described previously (Robertson et al. 1982).

\section{Preparation of adipocytes and adipocyte membranes}

Adipocytes were prepared by collagenase digestion and washed as described previously (Vernon et al. 1995). They were disrupted by suspension in $10-15 \mathrm{ml} 10 \mathrm{mM}$ Tris $/ \mathrm{HCl}, \mathrm{pH} 7 \cdot 4$, containing $20 \mathrm{mM}$ EDTA, $200 \mathrm{mM}$ sucrose, $17.5 \mu \mathrm{g} / \mathrm{ml}$ benzamidine $/ \mathrm{HCl}$ and $0.2 \mathrm{mM}$ phenylmethanesulphonyl fluoride at $40{ }^{\circ} \mathrm{C}$ and vortex-mixed for $2 \mathrm{~min}$. This preparation was immediately centrifuged at $2800 \mathrm{~g}$ for $5 \mathrm{~min}$ at $22{ }^{\circ} \mathrm{C}$; this minimises trapping of membranes within the lipid layer. The infranatant was removed, diluted to $50 \mathrm{ml}$ with ice-cold $10 \mathrm{mM}$ Tris/ $\mathrm{HCl}, \mathrm{pH} 7 \cdot 4$, containing $90 \mathrm{mM} \mathrm{NaCl}$, and centrifuged at $42000 \mathrm{~g}$ for $30 \mathrm{~min}$ at $4{ }^{\circ} \mathrm{C}$. The membrane pellet was resuspended in $50 \mathrm{mM}$ Tris $/ \mathrm{HCl}, \mathrm{pH} 7 \cdot 4$, containing $10 \mathrm{mM} \mathrm{MgCl} 2$, snap-frozen and stored in liquid $\mathrm{N}_{2}$. The protein concentration of the membranes was determined by the Bradford (1976) method using BSA as standard.

\section{Receptor binding and GTP-binding protein concentration of adipocyte membranes}

Ligand binding to adenosine receptors was assessed essentially as described previously (Watt et al. 1991). Adipocyte membranes $(200 \mu \mathrm{g}$ protein $/ \mathrm{ml})$ were preincubated in $50 \mathrm{mM}$ Tris/ $\mathrm{HCl}$ (pH 7.4) plus $10 \mathrm{mM}$ $\mathrm{MgCl}_{2}$ containing $1 \mu \mathrm{g} / \mathrm{ml}$ adenosine deaminase for $10 \mathrm{~min}$ at $37^{\circ} \mathrm{C}$ to remove endogenous adenosine, and then incubated at $37^{\circ} \mathrm{C}$ for a further 10 min with either $20 \mathrm{nM}\left[{ }^{3} \mathrm{H}\right] \mathrm{PIA}$ or a range of $\left[{ }^{3} \mathrm{H}\right] \mathrm{PIA}$ concentrations in a final volume of $0 \cdot 2 \mathrm{ml}$. [ ${ }^{3} \mathrm{H}$ ]PIA, $49 \mathrm{Ci} / \mathrm{mmol}$, was from Amersham International, Amersham, Bucks, UK. Nonspecific binding was determined by the addition of $100 \mu \mathrm{M}$ PIA. Incubations were stopped by the addition of $5 \mathrm{ml}$ ice-cold incubation buffer. The contents of each assay tube were then immediately filtered under vacuum through Whatman GF/C filter discs $(2.5 \mathrm{~cm}$ diameter). The filters were washed with $2 \times 5 \mathrm{ml}$ ice-cold incubation buffer and dried under vacuum. Filters were placed in $10 \mathrm{ml}$ Opti-Fluor scintillant to measure radioactivity.

The amounts of G-protein $\alpha$ subunits were determined by immunoblotting after separation by SDS-PAGE as described previously (Strassheim et al. 1990, Vernon et al. 1995). Anti-peptide sera (CSI, SGI and 13B) that specifically recognised the two isoforms (42 and $45 \mathrm{kDa}$ ) of the stimulatory (with respect to adenylate cyclase) GTPbinding protein, $\mathrm{G}_{\mathrm{s}}(\mathrm{CSI}), \mathrm{G}_{\mathrm{i}} 1$ plus $\mathrm{G}_{\mathrm{i}} 2$ (SGI) and $\mathrm{G}_{\mathrm{i}} 3$ (13B) were raised in house and characterised as described previously (Mitchell et al. 1989, Vernon et al. 1995). After autoradiography, the relative amounts of the G-protein $\alpha$ subunits were determined by densitometry. 
ADP-ribosylation of membrane proteins

Pertussis toxin-stimulated ADP-ribosylation of $G_{i}$ was performed as described by McKenzie (1992) with modifications. Pertussis toxin $(1 \mu \mathrm{g} / \mathrm{ml})$ was activated by preincubation with $50 \mathrm{mM}$ dithiothreitol plus $0.08 \mathrm{mM}$ ATP for $60 \mathrm{~min}$ at room temperature. ADP-ribosylation was performed using $250 \mathrm{mM}$ sodium phosphate, $\mathrm{pH} 7 \cdot 0$, $20 \mathrm{mM}$ thymidine, $1 \mathrm{mM}$ ATP, $0 \cdot 1 \mathrm{mM}$ GTP, $20 \mathrm{mM}$ arginine, $10 \mu \mathrm{g} / \mathrm{ml}$ activated pertussis toxin and $10 \mu \mathrm{M}$ $\left[{ }^{32} \mathrm{P}\right]$ NAD; incubation was for $2 \mathrm{~h}$ at $37^{\circ} \mathrm{C}$. The reaction was terminated by the addition of $1 \mathrm{ml}$ ice cold $50 \mathrm{mM}$ Tris/ $\mathrm{HCl}$, pH 7·5, containing $100 \mu \mathrm{M}$ phenylmethylsulphonyl fluoride and $1 \mathrm{mg} / \mathrm{ml}$ leupeptin. Labelled membranes were collected by centrifugation $(14000 \mathrm{~g}$, for $10 \mathrm{~min}$ at $4{ }^{\circ} \mathrm{C}$ ); they were separated by SDS-PAGE, detected by autoradiography (McKenzie 1992) and quantified by densitometry.

\section{Assay of adenylate cyclase activity}

This was determined essentially as described by Heyworth \& Houslay (1983). Briefly, the reaction conditions employed the use of a medium containing $5 \mathrm{mM} \mathrm{MgSO}_{4}$, $10 \mathrm{mM}$ theophylline, $1 \mathrm{mM}$ EDTA, $22 \mathrm{mM}$ disodium phosphocreatine, $1.5 \mathrm{mM}$ ATP, $1 \mathrm{mM}$ dithiothreitol, $1 \mathrm{mg}$ creatine kinase/ml and $25 \mathrm{mM}$ triethanolamine/ $\mathrm{KOH}, \mathrm{pH} 7 \cdot 4$. Incubations were carried out over $10 \mathrm{~min}$, using a final volume of $0.1 \mathrm{ml}$ with $3-7 \mu \mathrm{g}$ protein at a temperature of $30^{\circ} \mathrm{C}$. In experiments where PIA was employed, theophylline was omitted from the assays and the non-methylxanthine cAMP phosphodiesterase inhibitor Ro-07-2956 was added at $0 \cdot 1 \mathrm{mM}$, together with 1 unit of adenosine deaminase $/ \mathrm{ml}$. Other agents were added as described in the text and tables. The amount of cAMP produced was measured as described by Whetton et al. (1983).

\section{Statistical analysis}

Each value contributing to a mean was obtained from a different sheep. Results were analysed by ANOVA or Student's $t$-test for paired observations, and are presented as means \pm S.E.M. or with S.E.D. (standard error of difference) as indicated in the text and tables or figure legends.

\section{Results}

Effects of GH on response of lipolysis to PIA and isoprenaline

The addition of PIA markedly inhibits isoprenalinestimulated lipolysis in sheep adipose tissue with an $\mathrm{ED}_{50}$ of about $2 \mathrm{nM}$ (Fig. 1). Maintenance of tissue in culture for $48 \mathrm{~h}$ in the absence of exogenous hormones resulted in a small decrease $(P<0 \cdot 05$; ANOVA $)$ in response to PIA

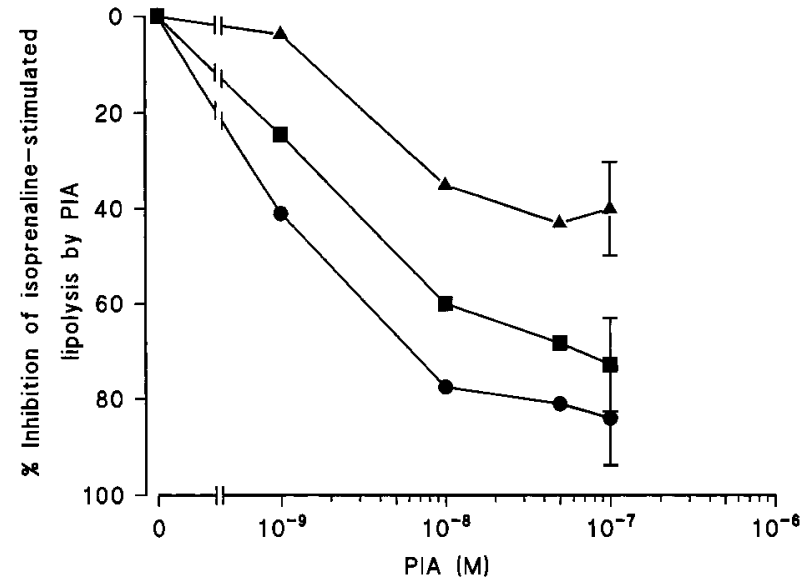

Figure 1 Effect of chronic exposure to $\mathrm{GH}$ on the ability of PIA to inhibit isoprenaline-stimulated lipolysis in sheep adipose tissue. Explants of sheep adipose tissue were maintained in culture for $22 \mathrm{~h}$ in the absence of exogenous hormones and then for a further $24 \mathrm{~h}$ with or without $4.5 \mathrm{nM} \mathrm{GH}$. Subsequently the ability of various concentrations of PIA to inhibit the rate of lipolysis stimulated by $10^{-5} \mathrm{M}$ isoprenaline plus adenosine deaminase was assessed. - , Tissue before culture; $\mathbf{\square}$, tissue cultured without $\mathrm{GH}$; $\boldsymbol{\Delta}$, tissue cultured with $\mathrm{GH}$ for the last $24 \mathrm{~h}$. Values are means of four observations, each from a different sheep; S.E.D., from

ANOVA, $9 \cdot 8$ (values for $100 \mathrm{nM}$ PIA are given as means \pm S.E.D.).

(Fig. 1). The addition of $\mathrm{GH}(4 \cdot 5 \mathrm{nM})$ during the last $24 \mathrm{~h}$ of culture markedly decreased the response to PIA $(P<0 \cdot 001$; ANOVA) (Fig. 1).

Pooling of results from a number of experiments, including that shown in Fig. 1, showed that tissue culture with $\mathrm{GH}$ for $24 \mathrm{~h}$ also induced a small but significant increase in the rate of basal (unstimulated) lipolysis $(P<0.001)$ and that stimulated by isoprenaline plus adenosine deaminase $(P<0.001)$; values were 4.51 and $3.86 \mu \mathrm{mol} / 3 \mathrm{~h}$ per $10^{6}$ cells for stimulated lipolysis after culture with and without GH respectively (s.E.D. 0-16) and 1.61 and $0.86 \mu \mathrm{mol} / 3 \mathrm{~h} 10^{6}$ cells for basal lipolysis after culture with and without $\mathrm{GH}$ respectively (s.E.D. $0 \cdot 15)$. Results are means of 26 observations.

A time course study showed that effects of GH on the response of lipolysis to PIA developed gradually over a $24 \mathrm{~h}$ period (Fig. 2). Basal lipolysis increased in response to GH with a similar time course to the change in response to PIA (results not shown). The effects of GH were lost if actinomycin $\mathrm{D}$, an inhibitor of transcription, was included during culture (Table 1).

\section{Effect of GH on components of the adenosine} signal-transduction system

$\left[{ }^{3} \mathrm{H}\right]$ PIA binding to the adenosine receptor was measured in adipocyte membrane preparations from tissue cultured with and without GH (Fig. 3); ANOVA showed that culture with $\mathrm{GH}$ had no effect on $\left[{ }^{3} \mathrm{H}\right]$ PIA binding. 


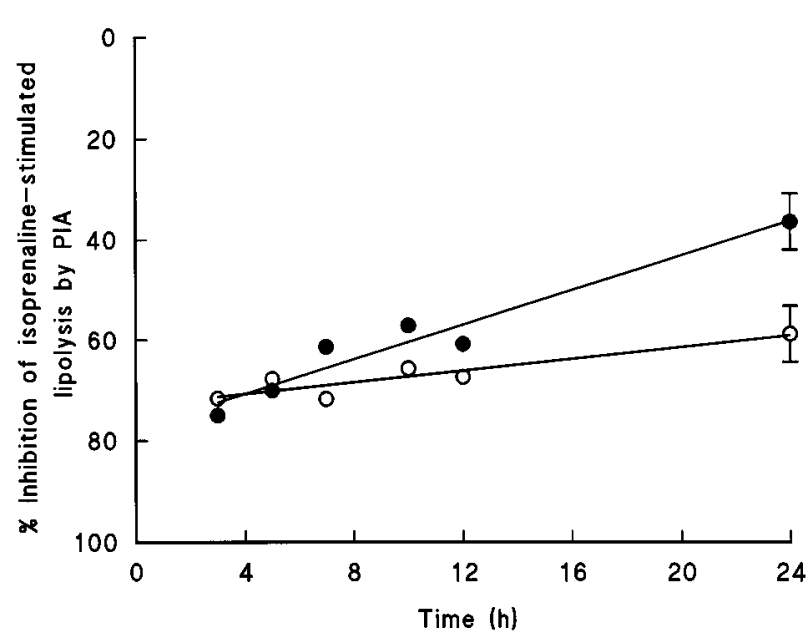

Figure 2 Time course of the development of the effect of GH on the response of lipolysis in sheep adipose tissue to PIA. Explants of sheep adipose tissue were maintained in culture for $22 \mathrm{~h}$ in the absence of exogenous hormones and then for periods up to $24 \mathrm{~h}$ with $(-)$ or without $(\bigcirc) 4.5 \mathrm{nM} \mathrm{GH}$. Subsequently the ability of $100 \mathrm{nM}$ PIA to inhibit lipolysis stimulated by $10^{-5} \mathrm{M}$ isoprenaline plus adenosine deaminase was assessed as described in the text. Values are means of three observations each from a different sheep; S.E.D. from ANOVA, 5.6 (values for $24 \mathrm{~h}$ given as means \pm S.E.D.).

Scatchard plots of the results presented in Fig. 3 were linear (not shown) and gave $K_{\mathrm{d}}$ values of $1.5 \pm 0.04$ and $2 \cdot 3 \pm 0 \cdot 09 \mathrm{nM}$ respectively for membranes from control and GH-treated adipocytes; corresponding $B_{\max }$ values were $228 \pm 12$ and $240 \pm 37$ fmol PIA bound/mg protein for membranes from control and GH-treated adipocytes respectively (means \pm S.E.M. obtained from regression analysis of Scatchard plots). Figure 3 shows that essentially maximum binding was achieved with concentrations of $\left[{ }^{3} \mathrm{H}\right] \mathrm{PIA}$ of $20 \mathrm{nM}$, as found previously with sheep adipocyte membranes (Vernon et al. 1995). [ $\left.{ }^{3} \mathrm{H}\right] \mathrm{PIA}$

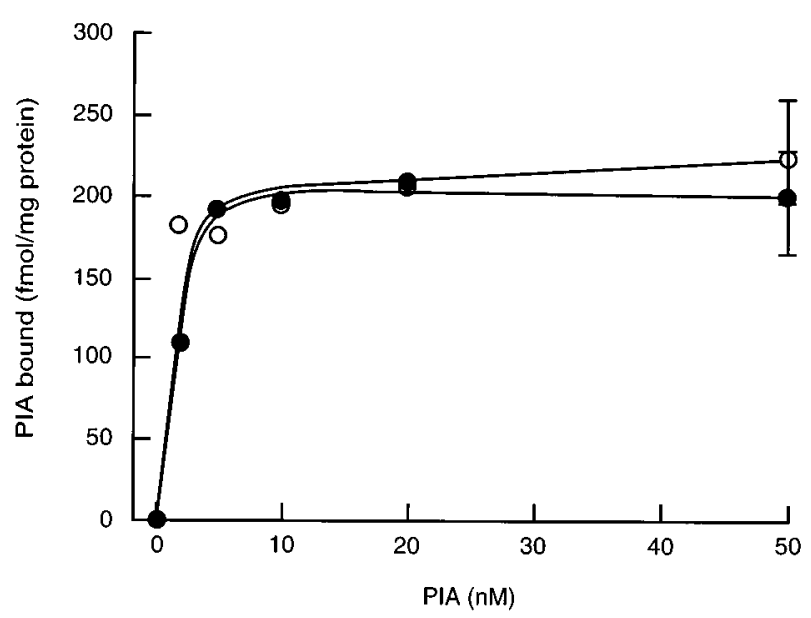

Figure 3 Effect of chronic exposure to $\mathrm{GH}$ on binding of $\left[{ }^{3} \mathrm{H}\right] \mathrm{PIA}$ to adenosine receptors. Explants of sheep adipose tissue were maintained in culture for $46 \mathrm{~h}$ in the absence $(\bigcirc)$ or presence of $4.5 \mathrm{nM} \mathrm{GH}$ during the last $24 \mathrm{~h}$. Subsequently adipocyte membranes were prepared and the amount of $\left[{ }^{3} \mathrm{H}\right] \mathrm{PIA}$ bound determined. Results are means of three observations, each from a different sheep; S.E.D. from ANOVA, 33 (values for 50 nM PIA given as means \pm S.E.D.).

binding was also assessed in three further experiments using a single concentration of $20 \mathrm{nM}$ PIA; pooling these values with corresponding values from Fig. 3 gave values of 211.1 and $215.2 \mathrm{fmol}$ PIA bound/mg protein for membranes from control and GH-treated adipocytes respectively; values are means of six observations, S.E.D. 8.3. Thus GH does not appear to alter maximum ligand binding to the adenosine receptor, suggesting that the number of adenosine receptors does not change in response to chronic exposure to $\mathrm{GH}$. Tissue culture with $\mathrm{GH}$ also had no effect on the amount of $\mathrm{G}_{\mathrm{i}} 1+\mathrm{G}_{\mathrm{i}} 2$ or $\mathrm{G}_{\mathrm{i}} 3$ (Table 2). These observations suggest that GH may exert its effects on the $\mathrm{G}_{\mathrm{i}}$-based antilipolytic system by altering

Table 1 Effect of actinomycin D on the ability of GH to modulate the lipolytic system of sheep adipose tissue. Explants of adipose tissue were maintained in culture for $22 \mathrm{~h}$ without added agents and then for a further $24 \mathrm{~h}$ with and without combinations of $\mathrm{GH}$ $(4.5 \mathrm{~nm})$ and actinomycin D $(80 \mathrm{~nm})$. Subsequently, the rates of basal lipolysis and that stimulated by isoprenaline (Isop.) $\left(10^{-5} \mathrm{M}\right)$ plus adenosine deaminase $(0 \cdot 8 \mu \mathrm{g} / \mathrm{ml})$ were measured and the ability of $100 \mathrm{nM}$ PIA to inhibit isoprenaline-plus-adenosine deaminase-stimulated lipolysis determined. Results are means of four observations

Inhibition of Isop.stimulated lipolysis by PIA (\%)

Addition to culture
None
GH
Actinomycin D
GH+actinomycin D
S.E.D.

Rate of lipolysis

\begin{tabular}{|c|c|}
\hline Isop.-stimulated & Basal \\
\hline $2 \cdot 83^{\mathrm{a}}$ & 0.60 \\
\hline $3 \cdot 57^{b}$ & 0.99 \\
\hline $2 \cdot 97^{\mathrm{a}}$ & $0 \cdot 60$ \\
\hline $2 \cdot 82^{\mathrm{a}}$ & 0.67 \\
\hline $0 \cdot 27$ & $0 \cdot 21$ \\
\hline
\end{tabular}

Values in a column without the same suffix $(a, b)$ differ significantly $(P<0 \cdot 05)$ (ANOVA). 
Table 2 Effect of culture with GH hormone on the amounts of G-proteins of sheep adipocyte membranes. Explants of adipose tissue were maintained in culture for $22 \mathrm{~h}$ in the absence of exogenous hormones and then for a further $24 \mathrm{~h}$ with and without $4.5 \mathrm{~nm} \mathrm{GH}$, after which adipocyte membranes were prepared and the amount of G-proteins assessed by immunoblotting and densitometry. Results are means \pm S.E.M. for three observations

\begin{tabular}{|c|c|c|c|c|}
\hline & Amount 0 & otein (arbitra & & \\
\hline & $\overline{\mathrm{G}_{\mathrm{i}} 1+2}$ & $\mathrm{G}_{\mathrm{i}} 3$ & $\mathrm{G}_{\mathrm{s}}(45 \mathrm{kDa})$ & $\mathrm{G}_{\mathrm{s}}(42 \mathrm{kDa})$ \\
\hline Treatment & & & & \\
\hline Control & $259 \pm 66$ & $555 \pm 93$ & $1150 \pm 39$ & $2287 \pm 55$ \\
\hline $\mathrm{GH}$ & $207 \pm 40$ & $496 \pm 128$ & $1271 \pm 103$ & $2539 \pm 66$ \\
\hline
\end{tabular}

the ability of $G_{i}$ to interact with either the adenosine receptor or adenylate cyclase, or both.

To explore the mechanism of the $\mathrm{GH}$ effect further, adipocyte membrane preparations were obtained from adipose tissue maintained in culture with and without GH. As shown in Table 3, culture with GH had no effect on basal or forskolin-stimulated (maximum) adenylate cyclase activity, nor was the ability of isoprenaline to activate adenylate cyclase altered. However, the ability of $10^{-7} \mathrm{M}$ PIA to inhibit isoprenaline-plus-GTP-stimulated adenylate cyclase activity was completely lost after culture with GH, whereas with membranes from control tissue, PIA caused a significant $(P<0 \cdot 05), 26 \cdot 2 \pm 4 \cdot 0 \%$, decrease in activity (Table 3 ). Thus the change elicited by $\mathrm{GH}$ in intact adipocytes is retained in membrane preparations.

Culture with GH had no effect on the amount of pertussis toxin-catalysed ADP-ribosylation of $\mathrm{G}_{\mathrm{i}}$ (3154 \pm 267 and $3472 \pm 267$ c.p.m./mg protein for membranes from cells after culture with and without $\mathrm{GH}$; results are means \pm s.E.M. for five observations). The addition of $1 \mu \mathrm{M}$ PIA during the ADP-ribosylation reaction decreased $(P<0 \cdot 01)$ the amount of ribosylation of $\mathrm{G}_{\mathrm{i}}$ by $36 \cdot 8 \pm 5 \cdot 9 \%$ and $37 \cdot 0 \pm 3 \cdot 9 \%$ of these membranes

Table 3 Effect of culture with GH on the adenylate cyclase activity of adipocyte membranes. Explants of adipose tissue were maintained in culture for $22 \mathrm{~h}$ and then for a further $24 \mathrm{~h}$ in the presence or absence of $4.5 \mathrm{nM} \mathrm{GH}$. Adipocyte membranes were then prepared and the adenylate cyclase activity assessed in the presence or absence of various effectors. Results are means \pm S.E.M. for four observations

\section{Effector}

Basal (none)

+ Isoprenaline $\left(10^{-4} \mathrm{M}\right)$

+ Forskolin $\left(10^{-4} \mathrm{M}\right)$

$+\operatorname{GTP}\left(10^{-5} \mathrm{M}\right)$

+ Isoprenaline + GTP

+ Isoprenaline + GTP+PIA $\left(10^{-7} \mathrm{M}\right)$

Adenylate cyclase activity ( $\mathrm{pmol} / \mathrm{min}$ per $\mathrm{mg}$ protein)

$\underline{\text { Control } \mathrm{GH}}$

$62 \pm 13$

$216 \pm 46$

$805 \pm 49$

$88 \pm 6$

$359 \pm 27$

$262 \pm 13$ from cells after culture with and without GH respectively (means \pm s.E.M. for five observations; no significant difference). The lack of effect of GH on the ability of PIA to decrease ADP-ribosylation was confirmed in a further experiment using a range of PIA concentrations (Fig. 4).

To assess $G_{i}$ activity independently of receptor activation, we measured the ability of guanosine $5^{\prime}-[\beta \gamma-$ imido]triphosphate $(\mathrm{p}[\mathrm{NH}] \mathrm{ppG})$, a non-hydrolysable analogue of GTP, to inhibit forskolin-stimulated adenylate cyclase activity (Strassheim et al. 1990). At low concentrations, $\mathrm{p}[\mathrm{NH}] \mathrm{ppG}$ is thought to activate only $\mathrm{G}_{\mathrm{i}}$ whereas at higher concentrations it activates both $G_{i}$ and $G_{\mathrm{s}}$ (Strassheim et al. 1990). As shown in Fig. 5, with membranes from control tissue, low concentrations of $\mathrm{p}[\mathrm{NH}] \mathrm{ppG}$ inhibited forskolin-stimulated adenylate cyclase activity $(P<0 \cdot 001$; ANOVA). In contrast, with

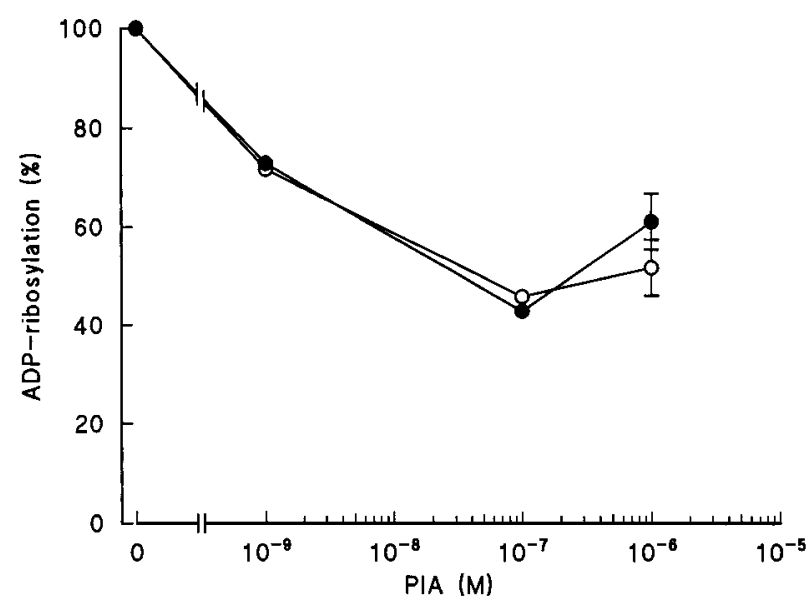

Figure 4 Effect of chronic exposure to GH on the ability of PIA to decrease pertussis toxin-catalysed ADP-ribosylation of sheep adipocyte membranes. Explants of sheep adipose tissue were maintained in culture for $46 \mathrm{~h}$ in the absence $(O)$ or presence of $4.5 \mathrm{nM} \mathrm{GH}$ during the last $24 \mathrm{~h}$. Subsequently adipocyte membranes were prepared and the amount of pertussis toxin-catalysed ADP-ribosylation determined in the presence and absence of various concentrations of PIA. Results are means of three observations, each from a different sheep; S.E.D. from ANOVA, $5 \cdot 7$ (values for $10^{-6} \mathrm{M}$ PIA given as means \pm S.E.D.). 


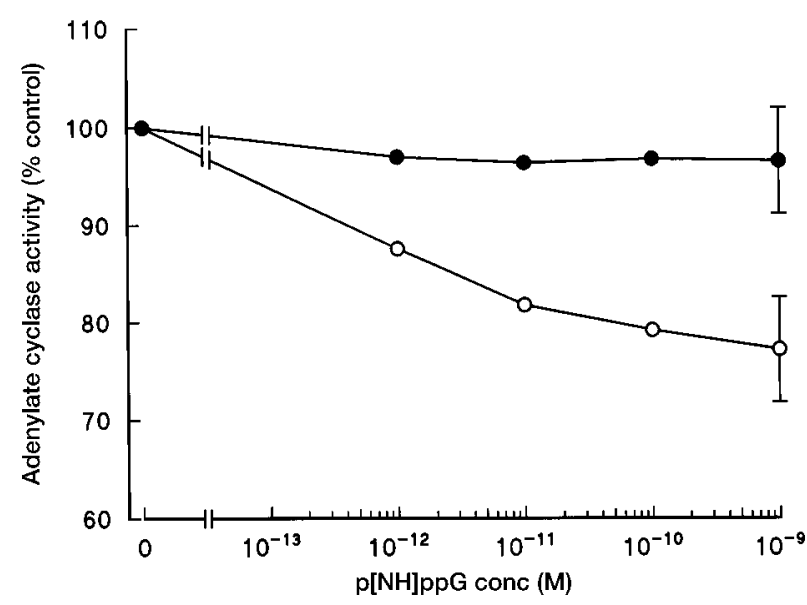

Figure 5 Effect of chronic exposure to $\mathrm{GH}$ on the ability of the GTP analogue, p[NH]ppG, to inhibit forskolin-stimulated adenylate cyclase activity of sheep adipocyte membranes. Explants of sheep adipose tissue were maintained in culture for $46 \mathrm{~h}$ in the absence $(\bigcirc)$ or presence $(0)$ of $4.5 \mathrm{nM} \mathrm{GH}$ during the last $24 \mathrm{~h}$. Subsequently adipocyte membranes were prepared and the ability of various concentrations of $\mathrm{p}[\mathrm{NH}] \mathrm{ppG}$ to inhibit forskolin $\left(10^{-4} \mathrm{M}\right)$-stimulated adenylate cyclase activity was determined. Values are means of four observations, each obtained from a different sheep; S.E.D. from ANOVA, $5 \cdot 4$ (values for $1 \mathrm{nM}$ $\mathrm{p}[\mathrm{NH}] \mathrm{ppG}$ given as means \pm S.E.D.).

membranes from tissue cultured with GH, p $[\mathrm{NH}] \mathrm{ppG}$ had no inhibitory effect on stimulated adenylate cyclase activity.

Effects of inhibitors of protein serine kinases and phosphatases

Evidence for a role for protein phosphorylation was sought using a protein serine kinase inhibitor, $\mathrm{H} 7$, and a protein serine phosphatase inhibitor, okadaic acid; the concentration of inhibitors used was based on findings from an earlier study (Vernon 1996) investigating the mechanism of the inhibition of lipogenesis by $\mathrm{GH}$ in sheep adipose tissue. At a concentration of $100 \mu \mathrm{M}, \mathrm{H} 7$ during culture prevented the effect of GH on PIA inhibition of lipolysis and also GH stimulation of basal lipolysis (Table 4). In the absence of GH, H7 had no effect on the response to PIA, basal lipolysis or isoprenaline-stimulated lipolysis (Table 4). Okadaic acid at $10 \mathrm{nM}$ mimicked the effect of $\mathrm{GH}$ on the response to PIA (Table 4); however, the effects of the two agents were additive (Table 4).

\section{Effect of PMA}

Acute exposure to PMA results in activation of some isoforms of protein kinase $\mathrm{C}$ (PKC), while chronic exposure to PMA leads to their downregulation and hence loss of activity (Dekker \& Parker 1994). Culture of explants of sheep adipose tissue with $10 \mu \mathrm{g} / \mathrm{ml}$ PMA, in the presence and absence of $\mathrm{GH}$, for $5 \mathrm{~h}$ after the usual $22 \mathrm{~h}$ preincubation, had no effect on either basal or isoprenalinestimulated lipolysis or the response to PIA $(n=3$, results not shown). Addition of $10 \mu \mathrm{g} / \mathrm{ml}$ PMA during either the second $24 \mathrm{~h}$ period of culture or during the whole $46 \mathrm{~h}$ period (i.e. added during the $22 \mathrm{~h}$ preincubation period as well as the $24 \mathrm{~h}$ culture period) had no effect on the changes in basal or isoprenaline-stimulated lipolysis or response to PIA induced by GH (Table 5); indeed, PMA partly mimicked the effects of $\mathrm{GH}$ on basal lipolysis and response to PIA (Table 5).

\section{Discussion}

Chronic treatment with GH in vitro decreases the antilipolytic effect of PIA on sheep adipose tissue, and thus mimics the effect of chronic treatment with GH in vivo of sheep (Doris et al. 1996) and cows (Dante et al. 1995,

Table 4 Effects of $\mathrm{H} 7$ and okadaic acid on the ability of GH to modulate the lipolytic system of sheep adipose tissue. Explants of adipose tissue were maintained in culture for $22 \mathrm{~h}$ without added agents and then for a further $24 \mathrm{~h}$ with and without combinations of $\mathrm{GH}$ $(4.5 \mathrm{nM}), \mathrm{H} 7(100 \mu \mathrm{M})$ and okadaic acid $(10 \mathrm{nM})$. Subsequently, the rates of basal lipolysis and that stimulated by isoprenaline (Isop.) $\left(10^{-5} \mathrm{M}\right)$ plus adenosine deaminase $(0 \cdot 8 \mu \mathrm{g} / \mathrm{ml})$ were measured and the ability of $100 \mathrm{nM}$ PIA to inhibit Isop.-plus-adenosine deaminase-stimulated lipolysis determined. Results are means of four observations

\section{H7}

\begin{tabular}{|c|c|c|}
\hline \multirow{2}{*}{$\begin{array}{l}\text { Inhibition of Isop.- } \\
\text { stimulated lipolysis by } \\
\text { PIA (\%) }\end{array}$} & \multicolumn{2}{|c|}{$\begin{array}{l}\text { Rate of lipolysis } \\
\left(\mu \mathrm{mol} \text { glycerol } / 3 \mathrm{~h} \text { per } 10^{6} \text { cells }\right)\end{array}$} \\
\hline & Isop.-stimulated & Basal \\
\hline $26 \cdot 1^{\mathrm{a}}$ & $4 \cdot 23^{a}$ & $0 \cdot 90^{\mathrm{a}}$ \\
\hline $10 \cdot 8^{b}$ & $4 \cdot 87^{\mathrm{ab}}$ & $1 \cdot 89^{b}$ \\
\hline $36 \cdot 0^{a}$ & $4 \cdot 44^{\mathrm{a}}$ & $0 \cdot 87^{\mathrm{a}}$ \\
\hline $34 \cdot 2^{\mathrm{a}}$ & $5 \cdot 83^{b}$ & $1 \cdot 20^{\mathrm{a}}$ \\
\hline $7 \cdot 2$ & $0 \cdot 34$ & $0 \cdot 25$ \\
\hline
\end{tabular}

Okadaic acid

\begin{tabular}{|c|c|c|}
\hline \multirow{2}{*}{$\begin{array}{l}\text { Inhibition of Isop.- } \\
\text { stimulated lipolysis } \\
\text { by PIA (\%) }\end{array}$} & \multicolumn{2}{|c|}{$\begin{array}{l}\text { Rate of lipolysis ( } \mu \mathrm{mol} \\
\text { glycerol } / 3 \mathrm{~h} \text { per } 10^{6} \text { cells) }\end{array}$} \\
\hline & $\begin{array}{l}\text { Isop.- } \\
\text { stimulated }\end{array}$ & Basal \\
\hline $44 \cdot 0^{\mathrm{a}}$ & $6 \cdot 24$ & $1 \cdot 80^{\mathrm{a}}$ \\
\hline $22 \cdot 8^{b}$ & $6 \cdot 70$ & $3 \cdot 75^{b}$ \\
\hline $18 \cdot 8^{\mathrm{b}}$ & $6 \cdot 62$ & $2 \cdot 57^{\mathrm{a}}$ \\
\hline $4 \cdot 3^{\mathrm{c}}$ & $6 \cdot 30$ & $4 \cdot 17^{b}$ \\
\hline $7 \cdot 3$ & $0 \cdot 70$ & 0.54 \\
\hline
\end{tabular}

Values in a column without the same suffix $(a, b, c)$ differ significantly $(P<0 \cdot 05)$ (ANOVA). 
Table 5 Effect of phorbol ester (PMA) on the ability of $\mathrm{GH}$ to modulate the lipolytic system of sheep adipose tissue. Explants of adipose tissue were maintained in culture either without exogenous agents or with PMA $(10 \mu \mathrm{g} / \mathrm{ml})$ for $22 \mathrm{~h}$ and then for a further $24 \mathrm{~h}$ with combinations of $\mathrm{GH}(4.5 \mathrm{nM})$ and PMA $(10 \mu \mathrm{g} / \mathrm{ml})$. Subsequently, the rates of basal lipolysis and that stimulated by isoprenaline (Isop.) $\left(10^{-5} \mathrm{M}\right)$ plus adenosine deaminase $(0 \cdot 8 \mu \mathrm{g} / \mathrm{ml})$ were measured and the ability of $100 \mathrm{nM}$ PIA to inhibit Isop.-plus-adenosine deaminase-stimulated lipolysis determined. Results are means of four observations

\begin{tabular}{|c|c|c|c|c|}
\hline \multicolumn{2}{|c|}{ Additions to culture } & \multirow{2}{*}{$\begin{array}{l}\text { Inhibition of Isop.- } \\
\text { stimulated lipolysis by PIA } \\
(\%)\end{array}$} & \multicolumn{2}{|c|}{$\begin{array}{l}\text { ( } \mu \mathrm{mol} \text { glycerol/3 h per } 10^{6} \\
\text { cells) }\end{array}$} \\
\hline $0-22 \mathrm{~h}$ & $22-46 \mathrm{~h}$ & & Isop. & Basal \\
\hline None & None & $60 \cdot 3^{a}$ & $3 \cdot 78$ & $0 \cdot 47^{a}$ \\
\hline None & $\mathrm{GH}$ & $38 \cdot 5^{\mathrm{b}}$ & 4.67 & $0.95^{b}$ \\
\hline None & PMA & $44 \cdot 5^{\mathrm{ba}}$ & $3 \cdot 67$ & $0 \cdot 56^{\mathrm{ac}}$ \\
\hline None & $\mathrm{PMA}+\mathrm{GH}$ & $36 \cdot 0^{\mathrm{b}}$ & $4 \cdot 54$ & $0 \cdot 94^{\mathrm{b}}$ \\
\hline PMA & PMA & $50 \cdot 8^{\mathrm{ab}}$ & $3 \cdot 60$ & $0 \cdot 86^{\mathrm{bc}}$ \\
\hline PMA & $\mathrm{PMA}+\mathrm{GH}$ & $40 \cdot 5^{b}$ & $4 \cdot 52$ & $1 \cdot 12^{\mathrm{b}}$ \\
\hline S.E.D. & & $7 \cdot 6$ & 0.58 & $0 \cdot 16$ \\
\hline
\end{tabular}

Values in a column without the same suffix $(a, b, c)$ differ significantly $(P<0 \cdot 05)$ (ANOVA).

Houseknecht et al. 1995, Houseknecht \& Bauman 1997) on this system. Furthermore the effects of GH in vitro on the antilipolytic effects of PIA do not appear to involve a change in ligand binding to adenosine receptors or the amount of $\mathrm{G}_{\mathrm{i}} 1+\mathrm{G}_{\mathrm{i}} 2$ or $\mathrm{G}_{\mathrm{i}} 3$, again in agreement with our previous studies with sheep (Doris et al. 1996) and cows (Houseknecht \& Bauman 1997) in which animals were chronically treated with GH in vivo. As forskolinstimulated adenylate cyclase activity did not change on $\mathrm{GH}$ treatment, it would appear that the amount of adenylate cyclase also is unchanged by $\mathrm{GH}$. These observations suggested that $\mathrm{GH}$ may exert its effects on the $\mathrm{G}_{\mathrm{i}}$-based antilipolytic system by altering the ability of $\mathrm{G}_{\mathrm{i}}$ to interact with either the adenosine receptor or adenylate cyclase, or both. As the effect of GH on the ability of PIA to inhibit the lipolytic system was retained in isolated membranes, it allowed further dissection of the basis of the GH effect.

Pertussis toxin elicits the ADP-ribosylation of the undissociated $G_{i}$ heterotrimer (Tsai et al. 1984, Wong et al. 1985); interaction of $G_{i}$ with the activated receptor causes dissociation of $G_{i}$ into the $\alpha$ subunit and the $\beta \gamma$ subunit with a concomitant decrease in pertussis toxin-catalysed ADP-ribosylation. Thus pertussis toxin-catalysed ADPribosylation along with determination of the total amount of $G_{i}$ by immunoblotting can provide an indication of the proportion of the heterotrimer that has dissociated into $\alpha$ and $\beta \gamma$ subunits. The decrease in pertussis toxin-catalysed ADP-ribosylation induced by PIA (Fig. 4) is consistent with PIA activation of the adenosine receptor, resulting in dissociation of heterotrimeric $\mathrm{G}_{\mathrm{i}}$. As $\mathrm{GH}$ did not alter the ability of PIA to decrease pertussis toxin-catalysed ADPribosylation, it would appear that the interaction of $G_{i}$ with the agonist-activated receptor is not altered by culture with $\mathrm{GH}$.
In contrast with the above, a recent study in which lactating cows were treated chronically with $\mathrm{GH}$ in vivo reported a diminished pertussis toxin-stimulated ADPribosylation of one or more $G_{i}$ isoforms of adipose tissue (Houseknecht \& Bauman 1997); these authors did not, however, examine the effects of GH on the ability of PIA to decrease pertussis toxin-stimulated ADP-ribosylation of $\mathrm{G}_{\mathrm{i}}$. This finding of Houseknecht \& Bauman (1997) is surprising as it suggests an enhanced dissociation of $G_{i}$ into its subunits in the GH-treated animals. The reason for the difference between their study and the data presented here is not clear; however, their membranes were prepared from whole adipose tissue taken by biopsy so it is possible that the enhanced dissociation of $G_{i}$ in the $G H$-treated cattle may reflect altered concentrations of agonists acting via $G_{i}$ in the tissue at the time of sampling. Whatever, if there was more undissociated $G_{i}$ in the $\mathrm{GH}$-treated cattle, it must presumably be less active to account for the decreased antilipolytic effect of PIA that they observed.

Assessment of $G_{i}$ activity independently of receptor activation using $\mathrm{p}[\mathrm{NH}] \mathrm{ppG}$ showed that, with membranes from control tissue, low concentrations of $\mathrm{p}[\mathrm{NH}] \mathrm{ppG}$ inhibited forskolin-stimulated adenylate cyclase activity to a similar extent to that found previously with rat adipocyte membranes (Strassheim et al. 1990, 1991). In addition to the present study, a diminished ability of $G_{i}$ to inhibit adenylate cyclase activity of adipocyte membranes has been found previously with preparations from streptozotocin-diabetic rats (Strassheim et al. 1990) and from obese ( $f a / f a)$ Zucker rats (Strassheim et al. 1991). As $\mathrm{p}[\mathrm{NH}] \mathrm{ppG}$ had no effect on forskolin-stimulated adenylate cyclase activity in membranes from tissue cultured with GH, it appears that the diminished ability of PIA, and probably other antilipolytic agents such as prostaglandin E, to inhibit lipolysis after chronic exposure 
of adipose tissue to $\mathrm{GH}$ is due to an impaired ability of $\mathrm{G}_{\mathrm{i}}$ to interact with adenylate cyclase. This suggests a covalent change, such as phosphorylation, to either isoform of $G_{i}$ (Houslay 1991, 1994, Morris et al. 1996) which couple to adenylate cyclase or the catalytic unit of adenylate cyclase itself (Taussig \& Gilman 1995).

The present study indicates involvement of at least one protein serine/threonine phosphorylation in the mechanism by which $\mathrm{GH}$ attenuates response to PIA. The identity of the protein serine/threonine kinases involved, however, is not clear. $\mathrm{H} 7$ can inhibit a number of protein kinases including protein kinase $\mathrm{A}$ (PKA) and PKC isoforms. PKA mediates the stimulation of lipolysis by isoprenaline. As $\mathrm{H} 7 \mathrm{had}$ no effect on either basal or isoprenaline-stimulated lipolysis, it appears that PKA was not inhibited by the concentration of $\mathrm{H} 7$ used. A concentration of $1 \mathrm{mM} \mathrm{H} 7$ was found to be required to inhibit basal lipolysis in sheep adipose tissue (Vernon 1996). Gorin et al. (1990) have suggested that the effects of $\mathrm{GH}$ on lipolysis in rat adipose tissue involve activation of PKC. This would not appear to be the case in sheep adipose tissue, as a $5 \mathrm{~h}$ exposure to PMA, which enhances the rate of lipogenesis in sheep adipose tissue (Vernon 1996), had no effect on the lipolytic system, while chronic exposure to PMA, which should lead to a loss of most, but not all, PKC isoforms, did not prevent the effects of $\mathrm{GH}$.

While a protein serine/threonine phosphorylation is supported by the studies with $\mathrm{H} 7$ and okadaic acid, the mechanism of GH action on the system is clearly complex, developing slowly over a $24 \mathrm{~h}$ period and involving an actinomycin D-sensitive step, presumably gene transcription. Earlier studies, carried out before the discovery of the adenosine-antilipolytic system, also showed that lipolytic effects of GH developed slowly and were prevented by inhibitors of gene transcription (Fain et al. 1965).

The effects of $\mathrm{GH}$ on the response to PIA resemble its chronic inhibitory effects on lipogenesis, which also develop slowly, and are prevented by actinomycin D and H7, again implicating gene transcription and protein serine/threonine phosphorylation (Vernon 1996). However, mechanisms involved in the chronic modulation of lipogenesis and lipolysis by GH in sheep adipose tissue are not identical, as okadaic acid mimicked the effect of $\mathrm{GH}$ on lipolysis but prevented the effect of $\mathrm{GH}$ on lipogenesis (Vernon 1996). In addition, chronic exposure to PMA partly prevented the effects of $\mathrm{GH}$ on lipogenesis (Vernon 1996) but tended to mimic the effects of GH on lipolysis.

Thus this and our previous study (Doris et al. 1994) show that GH can alter the ability of antilipolytic agents, which act via $G_{i}$, to inhibit lipolysis by at least two mechanisms: through a change in the concentration of $\mathrm{G}_{\mathrm{i}} 2$ and through a change in the ability of one or more isoforms of $G_{i}$ to interact with adenylate cyclase. The latter involves a mechanism that appears to involve both gene transcription and protein serine/threonine phosphorylation.

\section{Acknowledgements}

This work was supported by the Scottish Office Agriculture, Environment and Fisheries Department, by a BBSRC scholarship to RAD and by grants from the MRC (to MDH) and the BBSRC (to RGV and MDH).

\section{References}

Beauville M, Harant I, Crampes F, Riviere D, Tauber MT, Tauber JP \& Garrigues M 1992 Effect of long-term rhGH administration in GH-deficient adults on fat cell epinephrine response. American Journal of Physiology 263 E467-E472.

Birnbaumer L, Abramowitz J \& Brown AM 1990 Receptor-effector coupling by G proteins. Biochimica et Biophysica Acta 1031 163-224.

Bradford MM 1976 A rapid and sensitive method for quantification of microgram quantities of protein utilising the principle of protein dye binding. Analytical Biochemistry 72 248-254.

Dante P, Lanna D, Houseknecht KL, Harris DM \& Bauman DE 1995 Effect of somatotropin treatment on lipogenesis, lipolysis, and related cellular mechanisms in adipose tissue of lactating cows. Journal of Dairy Science 78 1703-1712.

Dekker LV \& Parker PJ 1994 Protein kinase C: a question of specificity. Trends in Biochemical Sciences 19 73-77.

Doris RA, Vernon RG, Houslay MD \& Kilgour E 1994 Growth hormone decreases the response to antilipolytic agonists and decreases the levels of $\mathrm{G}_{\mathrm{i}}-2$ in rat adipocytes. Biochemical Journal 297 $41-45$.

Doris R, Thompson GE, Finley E, Kilgour E, Houslay MD \& Vernon RG 1996 Chronic effects of somatotropin treatment on response of subcutaneous adipose tissue lipolysis to acutely acting factors in vivo and in vitro. Journal of Animal Science 74 562-568.

Fain JN, Kovacev VP \& Scow RO 1965 Effect of growth hormone and dexamethasone on lipolysis and metabolism in isolated fat cells of the rat. Journal of Biological Chemistry 240 3522-3529.

Goodman HM, Gorin E \& Honeyman TW 1988 Biochemical basis for the lipolytic activity of growth hormone. In Human Growth Hormone, pp 75-111. Ed LE Underwood. New York: Marcel Dekker, Inc.

Gorin E, Tai L-R, Honeyman TW \& Goodman HM 1990 Evidence for a role of protein kinase $\mathrm{C}$ in the stimulation of lipolysis by growth hormone and isoproterenol. Endocrinology 126 2973-2982.

Hanson RW \& Ballard FJ 1968 Citrate, pyruvate and lactate contaminants of commercial serum albumin. Journal of Lipid Research $9667-668$.

Heyworth CM \& Houslay MD 1983 Challenge of hepatocytes by glucagon triggers a rapid modulation of adenylate cyclase activity in isolated membranes. Biochemical Journal 214 93-98.

Houseknecht KL \& Bauman DE 1997 Regulation of lipolysis by somatotropin: functional alteration of adrenergic and adenosine signalling in bovine adipose tissue. Journal of Endocrinology 152 465-475.

Houseknecht KL, Bauman DE, Carey GB \& Mersmann HJ 1995 Effect of bovine somatotropin and food deprivation on $\beta$-adrenergic and $\mathrm{A}_{1}$ adenosine receptor binding in adipose tissue of lactating cows. Domestic and Animal Endocrinology 12 325-336.

Houslay MD $1991 \mathrm{G}_{\mathrm{i}}-2$ is at the centre of an active phosphorylation/dephosphorylation cycle in hepatocytes: the fine-tuning of stimulatory and inhibitory inputs into adenylate cyclase in normal and diabetic states. Cell Signalling 3 1-9.

Houslay MD 1994 Protein kinase C and the modulation of G-protein-controlled adenylyl cyclase and other signal transmission systems. In Regulation of Cellular Signal Transduction Pathways by Desensitisation and Amplification, pp 129-168. Eds DR Sibley \& MD Houslay. Chichester: John Wiley and Sons. 
Kalkbrenner F, Dippel E, Wittig B \& Schultz G 1996 Specificity of interaction between receptor and $G$ protein: use of antisense techniques to relate G-protein subunits to function. Biochimica et Biophysica Acta 1314 125-139.

Krebs HA \& Henseleit K 1933 Urea formation in the animal body. Hoppe-Seyler's Zeitschift für Physiologische Chemie 210 33-66.

McKenzie FR 1992 Basic techniques to study G-protein function. In Signal Transduction: A Practical Approach, pp 31-56. Ed G Milligan. Oxford: Oxford University Press.

Mitchell FI, Griffiths SL, Saggerson ED, Houslay MD, Knowler JT \& Milligan G 1989 Guanine-nucleotide-binding proteins expressed in rat white adipose tissue. Biochemical Journal 262 403-408.

Morris NJ, Bushfield M \& Houslay MD 1996 Streptozotocin-induced diabetes elicits the phosphorylation of hepatocyte $\mathrm{G}_{\mathrm{i}} 2$ at the protein kinase $\mathrm{C}$ site but not at the protein kinase A-controlled site. Biochemical Journal 315 417-420.

Plested CP, Taylor E, Brindley DN \& Vernon RG 1987 Interactions of insulin and dexamethasone in the control of pyruvate kinase activity and glucose metabolism in sheep adipose tissue. Biochemical Journal 247 459-465.

Robertson JP, Faulkner A \& Vernon RG 1982 Regulation of glycolysis and fatty acid synthesis from glucose in sheep adipose tissue. Biochemical Journal 206 577-586.

Rudolph U, Spicher K \& Birnbaumer L 1996 Adenylyl cyclase inhibition and altered $G$ protein subunit expression and ADPribosylation patterns in tissues and cells from $\mathrm{G}_{\mathrm{i}} 2 \alpha-/-$-mice. Proceedings of the National Academy of Sciences of the USA 93 3209-3214.

Strassheim D, Milligan G \& Houslay MD 1990 Diabetes abolishes the GTP-dependent, but not the receptor-dependent inhibitory function of the inhibitory guanine-nucleotide-binding regulatory protein $\left(\mathrm{G}_{\mathrm{i}}\right)$ on adipocyte adenylate cyclase activity. Biochemical Journal 266 521-526.

Strassheim D, Palmer T, Milligan G \& Houslay MD 1991 Alterations in G-protein expression and the hormonal regulation of adenylate cyclase in the adipocytes of obese $(f a / f a)$ Zucker rats. Biochemical Journal 276 197-202.

Taussig R \& Gilman AG 1995 Mammalian membrane-bound adenylyl cyclases. Journal of Biological Chemistry 270 1-4.
Tsai S-C, Adamik R, Kanaho Y, Hewlett EL \& Moss J 1984 Effects of guanyl nucleotides and rhodopsin on ADP-ribosylation of the inhibitory GTP-binding component of adenylate cyclase by pertussis toxin. Journal of Biological Chemistry 259 15320-15323.

Vernon RG 1996 GH inhibition of lipogenesis and stimulation of lipolysis in sheep adipose tissue: involvement of protein serine phosphorylation and dephosphorylation and phospholipase C. Journal of Endocrinology 150 129-140.

Vernon RG, Finley E \& Flint DJ 1987 Role of growth hormone in the adaptations of lipolysis in rat adipocytes during recovery from lactation. Biochemical Journal 242 931-934.

Vernon RG, Piperova L, Watt PW, Finley E \& Lindsay-Watt S 1993 Mechanisms involved in the adaptations of the adipocyte adrenergic signal-transduction system and their modulation by growth hormone during the lactation cycle in the rat. Biochemical Journal 289 845-851.

Vernon RG, Doris R, Finley E, Houslay MD, Kilgour E \& LindsayWatt S 1995 Effects of lactation on the signal transduction systems regulating lipolysis in sheep subcutaneous and omental adipose tissue. Biochemical Journal 308 291-296.

Watt PW, Finley E, Cork S, Clegg RA \& Vernon RG 1991 Chronic control of the $\beta$ - and $\alpha_{2}$-adrenergic systems of sheep adipose tissue by growth hormone and insulin. Biochemical Journal 273 39-42.

Whetton AD, Needham L, Dodd NJF, Heyworth CM \& Houslay MD 1983 Forskolin and ethanol both perturb the structure of liver plasma membranes and activate adenylate cyclase activity. Biochemistry and Pharmacology 32 1601-1608.

Wong SKF, Martin BR \& Tolkovsky AM 1985 Pertussis toxin substrate is a guanosine $5^{\prime}-[\beta$-thio]diphosphate-, N-ethylmaleimide-, $\mathrm{Mg}^{2+}$ - and temperature-sensitive GTP-binding protein. Biochemical Journal 232 191-197.

Yang S, Xu X, Björntorp P \& Edén S 1995 Additive effects of growth hormone and testosterone on lipolysis in adipocytes of hypophysectomized rats. Journal of Endocrinology 147 147-152.

Received 2 June 1997

Revised manuscript received 11 February 1998 Accepted 3 April 1998 